\title{
SITUS LIANGAN Ragam Data, Kronologi, dan Aspek Keruangan
}

\author{
LIANGAN SITE \\ Data Variability, Chronology, and Spatial Aspect
}

\author{
Sugeng Riyanto
}

\begin{abstract}
The extensive early Mataram period ( $6^{\text {th }}$ to $10^{\text {th }}$ centuries A.D.) site of Liangan located on the slopes of the Sindoro volcano in Temanggung Regency has been under an ongoing long term research project by the Yogyakarta Archaeological Centre since 2009. This project will continue from 2015 until 2019. The first term of excavations has disclosed numerous important data relating to the age, extent and nature of the site as well as former environmental, geological and environmental data. Spatial aspects of this important Ancient Mataram site which covers an area of more than 5 hectares relate to former residential, sacral and agricultural activities. Wellpreserved carbonized organic remains are an important feature of the site that reflect both agricultural and dietary features suggesting the impact of a volcanic eruption.
\end{abstract}

Keywords: Liangan, Settlement site, Ancient Mataram

\begin{abstract}
ABSTRAK
Situs Liangan di Kabupaten Temanggung merupakan situs yang sedang diteliti oleh Balai Arkeologi Yogyakarta sejak 2009, dan akan dilanjutkan setidaknya hingga program jangka menengah ke-dua pada 2015-2019. Program penelitian jangka menengah pertama yang berkahir pada 2014 menghasilkan sejumlah data dan informasi mengenai Liangan sebagai situs permukiman. Hal itu tercermin dari keragaman data yang meliputi sruktur dan bangunan batu dan fitur lainnya, artefak, organik, serta data geologis dan lingkungan. Kronologi situs Liangan berada pada rentang abad ke-6 hingga abad ke-10 Masehi sehingga terkait dengan masa Mataram Kuno. Secara keruangan, situs Liangan meliputi area hunian, area peribadata, dan area pertanian.
\end{abstract}

Kata kunci: Liangan, Situs permukiman, Mataram Kuno

Tanggal masuk : 11-03-2015

Tanggal diterima : 14-04-2015 


\section{PENDAHULUAN}

Pada 2000 Balai Arkeologi Yogyakarta meninjau situs dengan didasarkan pada informasi warga tentang ditemukannya struktur batu di halaman rumah seorang warga Dusun Liangan, Desa Purbosari, Kecamatan Ngadirejo, Kabupaten Temanggung. Secara astronomis, lokasi yang berada di tengah permukiman tersebut terletak pada $S 7^{0} \quad 15^{\prime} \quad 01.8 " \mathrm{E} 110^{\circ} \quad 01^{\prime}$ 44.8" dengan ketinggian dari permukaan air laut sekitar 1.100 meter. Idenitifikasi oleh tim menyebutkan bahwa struktur tersebut merupakan struktur yang dibangun dari balokbalok batu dan membentuk konstruksi yang cenderung memanjang dengan orientasi vertikal sekitar $80^{\circ}$ atau hampir tegak (Rangkuti dan Baskoro D.T., 2000). Belum ada penjelasan lebih jauh atas temuan tersebut, namun diduga bahwa konstruksi seperti itu berkaitan dengan peradaban masa Mataram Kuna. Selain dari karakteristik bahan dan teknologi tinggalan tersebut, Dusun Liangan juga berada pada kawasan lereng Sindoro yang memang menyimpan banyak data arkeologi masa Mataram Kuna, sehingga temuan tersebut dikaitkan dengan masa itu(Riyanto, 2011: 45)

Delapan tahun kemudian, yaitu pada 2008, lahan di atas perkampungan Dusun Liangan, tepatnya di barat sungai, menjadi lokasi galian tipe $\mathrm{C}$, dan pada akhir 2008 ditemukan data arkeologi berupa talud, komponen bangunan candi, arca, yoni, dan fragmen artefak keramik maupun tembikar. Pada awal 2009 Balai Arkeologi Yogyakarta mengadakan peninjauan temuan tersebut serta mengembangkan survei yang hasilnya adalah potensi Liangan sebagai situs yang kompleks dan penting berkaitan dengan peradaban Mataram Kuno, sekitar abad IX - X Masehi. Berdasarkan hasil tersebut direkomendasikan untuk menyusun program penelitian situs Liangan sebagai bagian program penelitian reguler Balai Arkeologi Yogyakarta. Sejak 2010 hingga 2014 situs Liangan menjadi salah satu situs unggulan yang dikembangkan dalam kerangka program jangka menengah pertama (2010 - 2014), jangka menengah ke-dua (2015 - 2019), dan seterusnya. Tahun 2014 adalah tahap akhir dari program jangka menengah pertama, berbagai data, pengetahuan, dan informasi mengenai seluk beluk peradaban Liangan kuno berhasil diperoleh dan disusun dalam berbagai bentuk, termasuk penjelasan hasil penelitian pada waktu pelaksanaan ekskavasi di lapangan kepada pengunjung maupun media.

"Orang nantinya nggak cuma tahu candi, tetapi bisa tahu bagaimana nenek moyangnya hidup dulu". Kalimat tersebut adalah salah satu pernyataan yang beberapa kali penulis lontarkan di hadapan para pewarta ketika penulis memimpin tim penelitian Balai Arkeologi Yogyakarta di situs Liangan pada 2014. Kalimat tersebut oleh Kompasdianggap kunci dalam proses penelitian sehingga dimuat di kompas.com, Senin, 24 November 2014, 07:30 WIB. Pengunjungdan bahkan wartawan yang ada di sana ketika itu awalnya tidak tertarik, bahkan tidak menaruh perhatian pada data arkeologi yang sedang diteliti pada kegiatan ekskavasi tersebut, padahal data itulah yang memicu semangat dan membuat gembira seluruh tim penelitian. Data itu "hanyalah" permukaan tanah dengan bercak-bercak arang di atasnya dan beberapa lubang, yang tentu saja sangat berarti bagi 
arkeolog dan sebaliknya tidak menarik bagi pengunjung maupun wartawan, kecuali setelah dijelaskan maknanya.

Hamparan tanah itu adalah permukaan tanah terakhir tempat beraktifitas nenek moyang sebelum diguyur hujan pasir panas, kemudian abu panas, dan selanjutnya material piroklastik Gunung Sindoro yang susul-menyusul menimbun permukiman kuno Liangan, lebih dari 1000 tahun yang lalu. Lubanglubang di permukaan tanah yang berukuran sekitar $10-15 \mathrm{~cm}$ dengan kedalaman bervariasi antara 20-30 $\mathrm{cm}$, membentuk jajarandalamdua baris, dan memanjang di permukaan tanah, adalah fitur bekas tiang kayu (lubang berbentuk persegi) dan tiang bambu (lubang berbentuk bundar). Beberapa lubang masih menyisakan arang organik di dalamnya.Tidak jauh dari tempat itu ditemukan potongan arang kayu yang diyakini bagian dari tiang tersebut yang terbakar, patah, kemudian terlempar pada saat erupsi Gunung Sindoro. Wajah-wajah serius pengunjung dan wartawan semakin tampak,bahkan kekaguman pada buah karya nenek moyang itu tidak mampu disembunyikan dari raut mereka. Diselingi beberapa pertanyaan dan penjelasan ilmiah oleh tim penelitian, tampaknya makna data hasil ekskavasi tersebut semakin membuat mereka bangga dan kagum pada peradaban kuno Liangan yang tercermin pada kehadiran data arkeologi berupa fitur dan data organik, selain candi.

Keistimewaan situs Liangan memang bukan terletak pada candi dan bangunan batu lainnya, tetapi yang membuatnya istimewa adalah integrasi dengan data berupa fitur, organik, artefak, serta lingkungan lereng Sindoro yang potensial sebagai lokasi permukimannamun menyimpan potensi bencana.Keseluruhan data itulah yang menjadi sasaran penelitian untuk dicari dan dikaji oleh Balai Arkelogi Yogakarta pada program penelitian jangka menengah pertama, sejak 2010 hingga 2014, dan akan dikembangkan pada program penelitian jangka menengah ke-dua pada 2015 hingga 2019, dan seterusnya. Integrasi sasaran penelitian arkeologi di Liangan sebagai situs permukiman yang kompleks dan bukan sekedar situs candi sejalan dengan harapan Boechari yang mengingatkan adanya segi lain dari masalah percandian. Berikut ini kutipan harapan tersebut:"Di dalam prasaran ini kami akan mengemukakan segi lain dari masalah percandian... Mudah-mudahan prasaran ini dapat memberi sumbangan pikiran bagi para ahli arkeologi yang hendak mengadakan penggalian penelitianatas suatu peninggalan candi di masa-masa yang akan datang"(Boechari, 1977: 94).

Ada kegalauan yang muncul setelah program penelitian jangka menengah pertama berakhir pada 2014 dengan berbagai hasil penelitian berupa data dan pengetahuan yang sudah diperoleh. Pemicu kegalauan tersebut adalah data kunjungan ke situs Liangan dari berbagai kalangan yang memperlihatkan grafik terus naik, sementara dominasi data arkeologi yang ada di situs adalah bangunan batuyang tidak tampak integrasinya dengan data lainnya.Kondisi ini dikarenakan situs Liangan masih dalam proses awal penelitian oleh Balai Arkeologi Yogyakarta dan awal proses pelestarian oleh BPCB Jawa Tengah, sehingga memang belum siap untuk dikunjungi. Sebagai akibatnya, pengunjung hanya akan mendapatkan gambaran situs 
Liangan sebagaimana yang tampak di lapangan yaitu struktur dan bangunan batu yang sepotongsepotongtanpa integrasi, apalagi dengan data lain yang tidak berada di lapangan karena masih diteliti atau diamankan.Penelitian oleh Balai arkeologi Yogyakarta memang dilakukan tahap demi tahap yang menghasilkan dan mengungkap situs Liangan bagaikan menyusun mozaik peradaban sepotong demi sepotong hingga berwujud sebagaimana yang dapat dilihat sekarang, tentu saja termasuk data lain yang integral. Keragaman data adalah kunci keistimewaan situs Liangan, dan secara khusus tulisan ini disusun untuk memaparkan hasil penelitian jangka menengah pertama dalam aspek ragam data, kronologi, serta aspek keruangan.

\section{KERANGKA METODOLOGI}

Kerangka dasar penelitian dalam program penelitian jangka menengah pertamadi Liangan adalah jenis penelitian deskriptifanalitik dengan penalaran induktif. Dalam metode ini,antara lain dilakukan analisis berbagai data arkeologi yang ditemukan di situs Liangan secara deskriptif untuk menjelaskan hal-hal yang berkaitan dengan permasalahan penelitian dan bersifat lebih umum yaitu mengenai keragaman bentuk data, kronologi, dan aspek keruangannya. Danim (2002: 41) menggambarkan bahwa penelitian deskriptif dimaksudkan untuk mendeskripsikan suatu situasi atau area populasi tertentu yang bersifat faktual secara sistematis dan akurat. Pengertian yang sama mengenai penelitian deskriptif antara lain juga dikemukakan oleh Azwar (1998: 5) dan Haryono (1993: 10) yang pada intinya mengemukakan bahwa penelitian jenis ini bertujuan untuk menggambarkan secara sestematis dan akurat mengenai populasi atau bidang tertentu. Sementara itu, menurut Sumanto (1995: 77) penelitian deskriptif analitis berusaha mendeskripsi dan menginterpretasi apa yang ada; dapat mengenai kondisi atau hubungan yang ada.

Dalam arkeologi terdapat tiga dimensi utama dalam kajianya, yaitu dimensi bentuk, dimensi waktu, dan dimensi ruang. Dalam perkembangan disiplin arkeologi, dimensi ruang (spatial) muncul belakangan dibandingkan dimensi bentuk (formal) maupun dimensi waktu (temporal) (Mundardjito, 2002: 70). Pandangan pada ketiga dimensi tersebut sebenarnya terkait dengan perubahan tekanan perhatiannya terutama dalam hal keruangan, yaitu dari artifact oriented, kemudian site oriented, dan akhirnya region oriented. Istilah ruang dalam kajian ini mengacu pada aspek keletakan, lokasi, atau tempat ditemukannya benda arkeologi dan situs di permukaan bumi. Dalam wacana arkeologi, hal ini dikenal sebagai konsep in situ (Mundardjito, 2002: 71).

Dalam konteks kebudayaan, terdapat lima pendekatan penelitian permukiman yang sering digunakan di Indonesia, yaitu meliputi kebudayaan materi, fungsi situs, lingkungan, sejarah, dan etnografi (Said, 2006: 4-5). Pendekatan kebudayaan materi adalah yang paling menonjol, meskipun secara kualitas dan kuantitas terbatas, karena peninggalan materi merupakan yang paling kentara. Hal ini karena peninggalan budaya materi dianggap mencerminkan pranata dan gagasan yang terkandung di dalamnya. Pendekatan ke-dua menempatkan situs ibarat tempat kejadian perkara atau TKP bagi detektif yang di 
dalamnya terdapat benda-benda, konteks, dan hubungan-hubungan yang dapat menjadi dasar untuk merekonstruksi peristiwa-peristiwa. Situs dianggap sebagai ruang dan tidak hanya diartikan sekedar tempat, tetapi menjadi konsep untuk memahami kerangka perilaku manusia masa lalu di situs tersebut. Pada pendekatan ke-tiga, pandangan bahwa manusia tergantung pada lingkungan alamnya harus diluruskan karena sesungguhnya hubungan antara manusia dan lingkungan alam juga sebagai hubungan dalam hal manusia mempengaruhi dan mengubah lingkungannya, walaupun lingkungan dapat mempengaruhi corak kebudayaan manusia. Pendekatan sejarah, pedekatan keempat, tentu saja mensyaratkan adanya data sejarah baik tertulis maupun lisan yang dapat melengkapi studi arkeologi permukiman, dan digunakan dalam konteks arkeologi sejarah. Meskipun sebenarnya data sejarah juga terbatas, namun dengan strategi analogi dalam pemanfaatannya, pendekatan sejarah dapat berguna untuk menjelaskan gejala-gejala arkeologis. Terakhir, pendekatan etnografi, dalam hal ini adalah analogi etnografi, ada yang menganggap sebagai kaidah tersendiri dan menjadi bagian dari prosedur penelitian arkeologi. Meskipun etnografi mampu memberikan kerangka umum untuk referensi dalam penelitian arkeologi, namun karena sering muncul subyektifitas etnograf maupun subyeknya, dan adanya bias oleh faktor-faktor perubahan budaya yang harus diperhitungkan, maka dalam hal ini arkeolog dituntut untuk selalu bersikap hati-hati (Said, 2006: 5-11).

David L. Clark (1977) yang dikutip oleh Mundardjito (1990: 22) mengatakan bahwa perkembangan studi permukiman dalam arkeologi terdapat tiga tingkatan dalam analisis pola persebaran dan hubungan, yang meliputi tingkat mikro, semi mikro (atau meso), dan makro. Tingkat mikro mencakup ruang sebuah bangunan yang di dalamnya meliputi persebaran ruangan dan hubungan antarruang di dalam satu bangunan yang antara lain berguna untuk mengetahui struktur sosial (keluarga) berdasarkan data seperti hierarki ruang, fungsi ruang, dan gaya bangunan. Hubungan antara unsurunsur bangunan dengan komponen lingkungan alam juga menjadi perhatian guna mengetahui kearifan lingkungan dari masyarakat dalam memanfaatkan sumberdaya alam dan menyesuaikan diri terhadap lingkungan alam. Cakupan dalam studi tingkat semi mikro adalah sebuah situs yang di dalamnya meliputi hubungan antara bangunanbangunan yang antara lain bertujuan untuk mengetahui struktur sosial (komunitas), ekonomi, politik, dan agama. Cakupan dalam tingkat makro adalah satu wilayah melalui studi persebaran dan hubungan antarsitus yang antara lain berguna untuk mengetahui struktur sosial (masyarakat), politik, ekonomi, dan kemampuan teknologi (Mundardjito, 1990: 23).

Dalam kerangka itu, fokus penelitian jangka menengah I memang difokuskan pada studi pada tingkat mikro dan semi mikro. Berkenaan dengan hal tersebut, dalam proses penelitian, khususnya dalam pelaksanaan ekskavasi, sangat penting untuk memperhatikan unsur-unsur permukiman dalam skala mikro maupun semi mikro. Kisaran unsur dalam permukiman tingkat mikro masa klasik antara lain meliputi 
lubang bekas tiang, fondasi, lantai, dinding, ruang-ruang, atap, jamban, sumur, selokan, lubang sampah, limbah, gapura, artefak, ekofak, dan fitur lainnya. Dalam masa klasik, kisaran unsur permukiman pada tingkat semi mikro meliputi jaringan selokan, jaringan kanal, jaringan jalan, bengkel industri, pasar, candi, gapura, pagar, lahan pertanian, dan sumberdaya alam (Mundardjito, 1990: 29).

\section{RAGAM DATA}

Liangan merupakan situs masa Mataram Kuno abad ke-9 - 10 Masehi yang memiliki komponen permukiman yang kompleks, yaitu area hunian, area peribadatan Hindu sebagimana dtunjukkan oleh temuan yoni dan lingga, area pertanian, dan area perbengkelan (Riyanto, 2011: 57-58; Riyanto, 2013: 767). Area hunian ditandai dengan ditemukannya sisa rumah kayu, peralatan rumah tangga dari keramik, tembikar, logam, dan batu. Area peribadatan Hindu ditandai oleh bangunan candi Hindu, bangunan batur, dan peralatan peribadatan berupa genta perunggu dan arca. Area pertanian ditandai oleh sebaran yoni di bagian atas situs, peralatan pertanian dari logam, dan sisa padi yang hangus terbakar oleh materi vulkanik. Data arkeologi di situs Liangan yang meliputi unsur-unsur permukiman memang sangat beragam yang secara integral sekaligus mencerminkan peradaban di Liangan kuno. Berikut ini diuraikan keragaman data arkeologi tersebut.

\section{Fitur}

Fitur dalam hal ini adalah data arkeologi yang tidak dapat dipindahkan tanpa merusak matriksnya, sedangkan matriks adalah materi yang melekat atau membungkus data arkeologi secara insitu. Data fitur di situs Liangan diuraikan berikut ini.

\section{Struktur dan Bangunan}

Secara garis besar, data arkeologi berupa struktur dan bangunan khususnya berbahan batu di Liangan meliputi (1) candi dan batur, (2) pagar dan talud, (3) jalan, selasar, dan tangga, (4) struktur boulder yang membentuk terasan. Berikut ini uraian ringkas struktur dan bangunan tersebut.

(1) Candi dan Batur

Keberadaan candi dan batur di situs Liangan hingga penelitian 2014 terdiri atas Candi 1, Candi 2, Batur 1, Batur 2a, Batur 2b, Batur 2c, Batur 2d, Batur 3, Batur 4, bangunan batu yang belum jelas apakah petirtaan atau candi, serta undakan atau terasan yang diperkuat dengan boulder.

Keletakan bangunan batur dan candi di situs Liangan pada peta situasi situs adalah sebagai berikut.

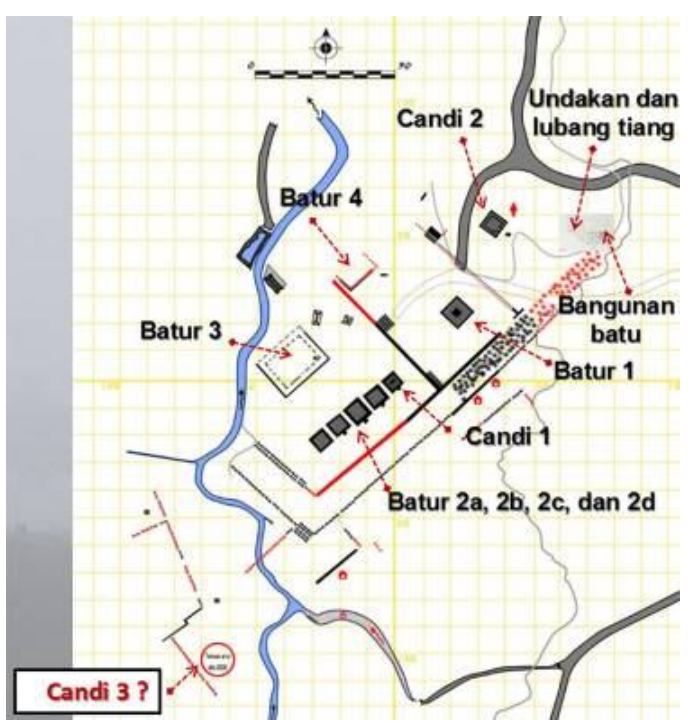

Gambar 1. Keletakan bangunan batur dan candi di situs Liangan 
Berikut gambaran candi dan batur tersebut yang ditemukan di situs Liangan hingga 2014.

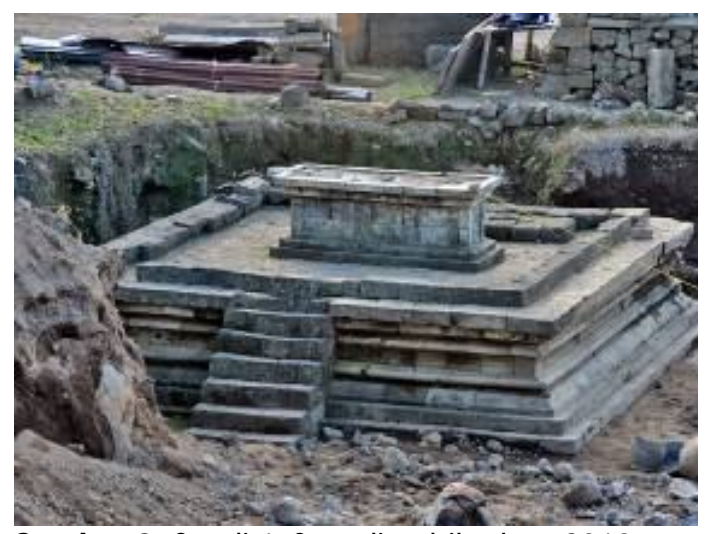

Gambar 2. Candi 1, foto diambil tahun 2010

Candi 1 ditemukan pada awal 2010. Bangunan ini berdenah bujursangkar dan berukuran $5,53 \mathrm{~m}$ x 5,53 m. Arah hadap candi 1 adalah timur laut, sebagaimana terindikasi pada letak tangganya. Foto diambil tahun 2010

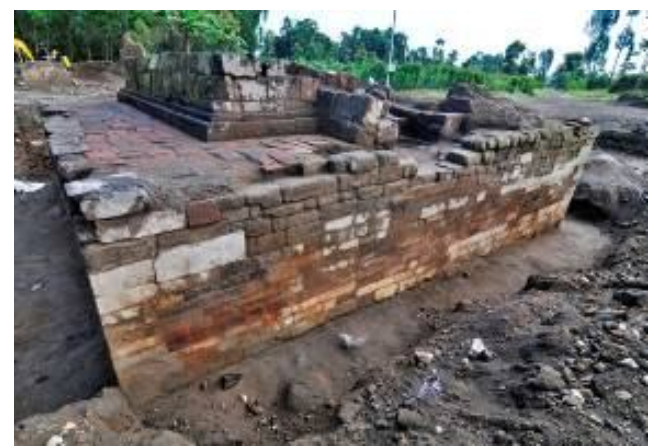

Gambar 3. Candi 2, foto dambil tahun 2014

Candi 2 yang ditemukan tahun 2012 awalnya diduga batur karena baru sebagian tampak. Hasil ekskavasi pada 2014 menunjukkan bahwa bangunan ini adalah candi yang memiliki bilik batu. Bentuk candi 2 adalah bujursangkar dengan ukuran 7,2 x 7, 2 meter. Arah hadap candi 2 adalah timur laut, sebagaimana terindikasi pada letak penampil biliknya.

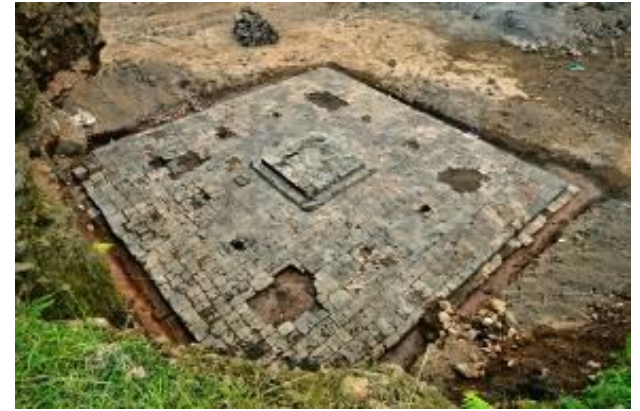

Gambar 4. Batur 1, foto diambil tahun 2012

Batur 1 ditemukan tahun 2012. Batur berdenah bujur sangkar dengan ukuran $8,40 \times 8,45$ meter. $\mathrm{Di}$ lantai batur terdapat lubang bekas tiang berjumlah 12, dan di bagian tengah lantai batur terdapat bentuk altar.

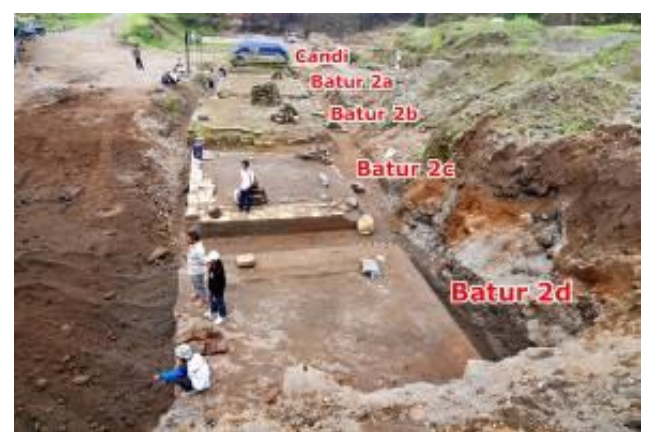

Gambar 5. Batur 2a, 2b, 2c, dan 2d, foto diambil tahun 2013

Batur2a, 2b, 2c, dan 2d yang mendampingi bangunan candi adalah hasil ekskavasi secara bertahap sejak 2012 dan 2013. Kecuali batur 2d, batur-batur ini dilengkapi dengan tangga di sisi timur laut sehingga arah hadapnya sama dengan candi 1 .

Batur 2a berbentuk bujur sangkar dengan ukuran 6,57 x 6,58 m2. Denah batur $2 \mathrm{~b}$ berbentuk persegi dengan ukuran 7,50 x 7,08 m2. Batur 2c berdenah persegi panjang dan berukuran 5,96 x 6,48 $\mathrm{m} 2$. Denah batur $2 \mathrm{~d}$ yang berbentuk persegi panjang berukuran 5,98 $\mathrm{x}$ $6,48 \mathrm{~m} 2$. 


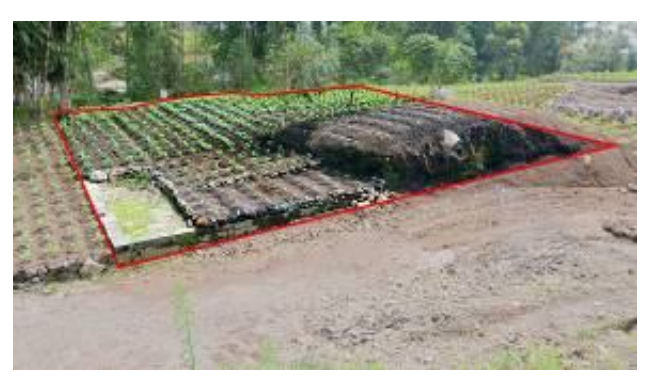

Gambar 6. Batur 3, foto diambil tahun 2012

Batur 3 pasca-ekskavasi 2012, baru sebagian yang terbuka, oleh BPCB selanjutnya dibuka seluruhnya. Bangunan ini rusak di bagian yang dekat dengan sungai, diperkirakan kerusakan itu karena gerusan aliran sungai Liangan. Denah pasti tidak diketahui dan salah satu sisinya berukuran panjang 21, 24 meter.

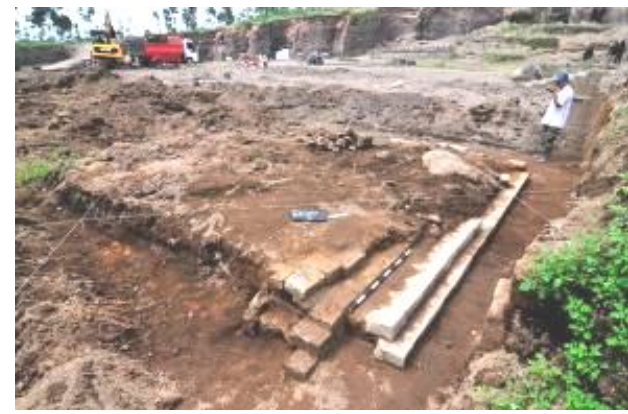

Gambar 7. Batur 4, foto diambil tahun 2014

Batur 4 kondisinya sangat rusak sehingga tidak dapat diketahui bentuk dan ukuran denahnya. Berdasarkan sisi terpanjang yang tersisa, diperkirakan batur ini berukuran lebih dari 10 meter sisi terpanjangnya. Batur 4 ditemukan dalam ekskavasi 2014.

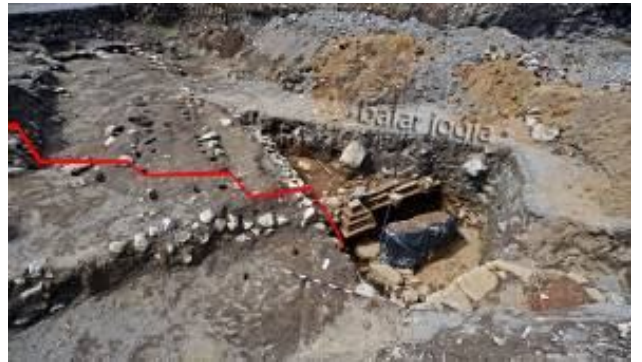

Gambar 8. Undakan atau terasan tanah, foto diambil tahun 2014

Undakan atau terasan tanah yang diperkuat dengan susunan boulder, hasil ekskavasi 2014. Dari lima undakan, hanya bagian tengah yang terdapat lubang-lubang bekas tiang kayu dan bambu. Susunan boulder paling bawah sekaligus merupakan talud, dan di bawahnya ditemukan bangunan batu yang belum dapat dipastikan apakah candi atau petirtaan.

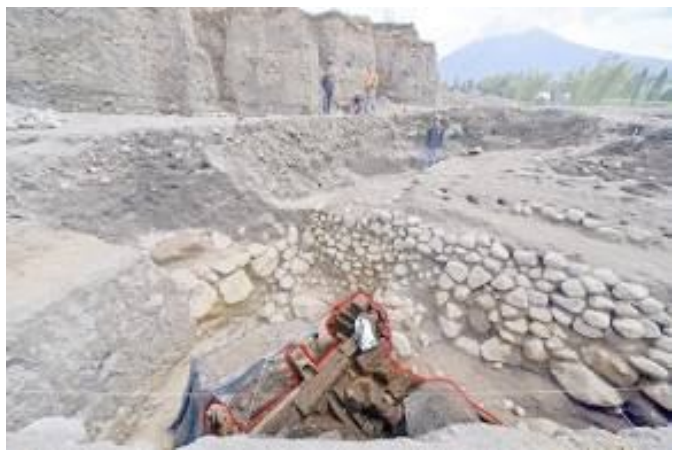

Gambar 8. Bagian sudut bangunan batu, foto diambil tahun 2014

Bangunan batu yang belum dapat dipastikan apakah candi atau petirtaan karena baru bagian sudut yang ditemukan. Salah satu sisi bangunan dilengkapi dengan jaladwara yang terhubung dengan selokan kecil di atas bangunan. Bangunan batu ini ditemukan dalam ekskavasi 2014.

(2) Pagar dan Talud Keletakan pagar dan talud di situs Liangan pada peta situasi situs adalah sebagai berikut. 


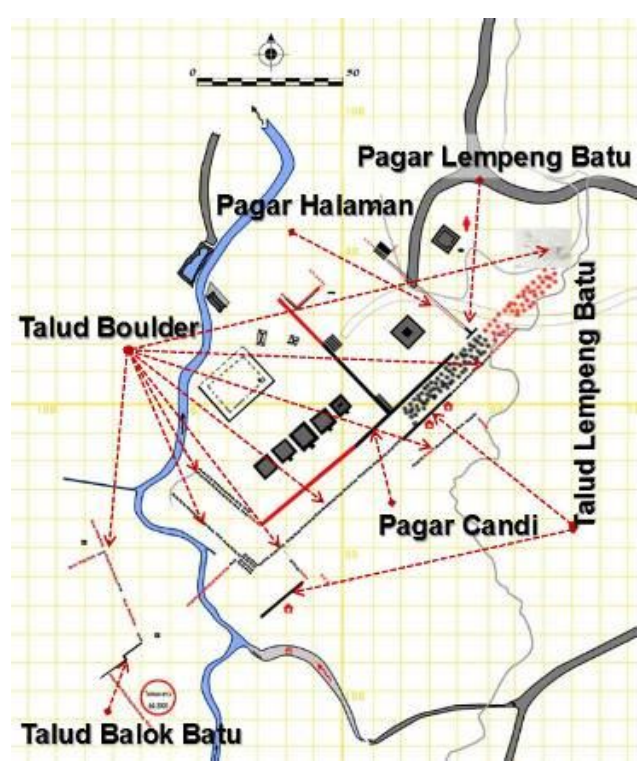

Gambar 9. Keletakan pagar dan talud di situs Liangan

Berikut ini adalah uraian singkat mengenai pagar dan talud tersebut.

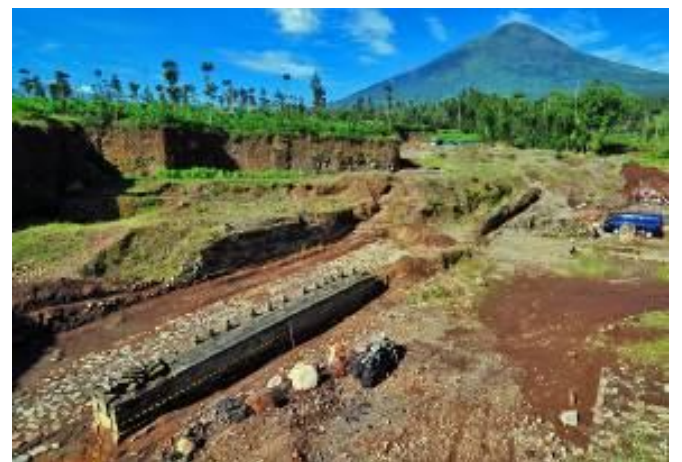

Gambar 10. Pagar candi, foto diambil tahun 2013

Pagar candi pertama ditemukan oleh Tim Penelitian Balai Arkeologi Yogyakarta pada 2011. Pada waktu itu yang ditemukan adalah bagian ujung pagar. Hasil ekskavasi hingga 2014 menunjukkan bahwa pagar candi tidak mengelilingi bangunan candi tetapi hanya berupa bujuran yang berorientasi timur laut - barat daya, sejajar dengan jalan batu.
Struktur yang menggunakan batu andesit ini berukuran lebar 1,34 meter, tinggi 1,65 meter, sedangkan berdasarkan singkapan pagar candi yang telah tampak mempunyai panjang \pm 80 meter.

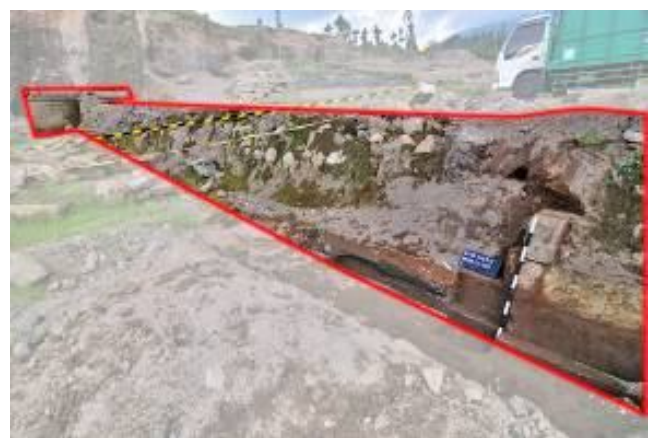

Gambar 11. Talud balok/lempeng batu yang menjadi pagar pemisah antara halaman I dengan halaman II area ibadah. Foto diambil tahun 2014

Kondisi struktur sudah tidak utuh sebagai akibat terjangan materi vulkanik sewaktu erupsi Gunung Sindoro maupun aktivitas penambangan. Bahan penyusun struktur talud adalah batu sedimen (tufaan ?) berbentuk balok berukuran panjang 53-84 cm dan tebal $18 \mathrm{~cm}$.

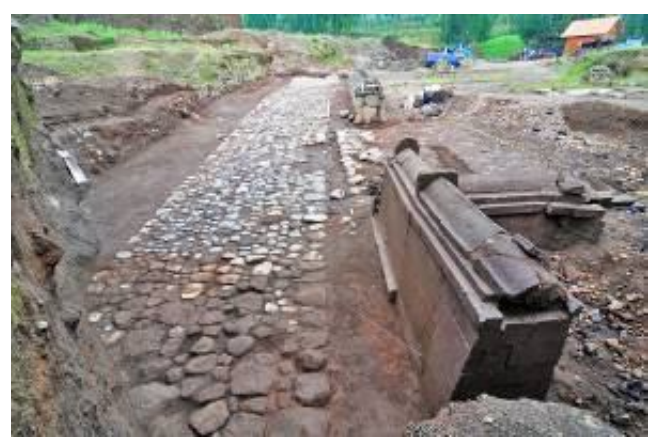

Gambar 12. Pagar lempeng batu, foto diambil tahun 2013

Pagar lempeng batu ini pertama ditemukan oleh penambang pada tahun 2012, dan pada 2013 dibuka melalui ekskavasi. Bahan penyusun pagar adalah lempengan batu fufaan dan bagian atas 
dilengkapi dengan penutup berbentuk setengah lingkaran. Struktur yang berbentuk seperti huruf $T$ ini merupakan penyekat beberapa area, yaitu jalan batu, pagar candi, dan pemisah antara halaman I dan halaman II (area peribadatan). Ukuran pagar adalah tinggi 1,75 - 2 meter, lebar 0,95 meter, sedangkan dimensi panjang pagar lempeng batu terdiri dari dua sisi, yaitu sisi yang berorientasi timur laut - barat daya mempunyai panjang 4,20 meter dan sisi yang berorientasi barat laut - tenggara berdasarkan singkapan yang nampak mempunyai panjang 2,60 meter.

Sebagai catatan, struktur dengan bentuk dan bahan yang sama ditemukan pada tahun 2000 di tengah permukiman Dusun Liangan.

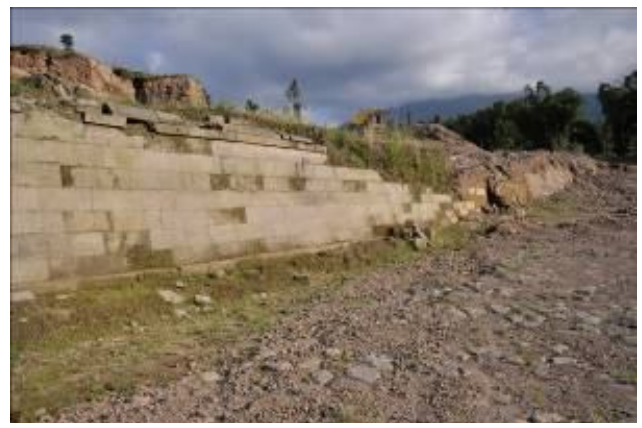

Gambar 13. Talud lempeng/balok batu yang sejajar dengan jalan batu, foto diambil tahun 2013

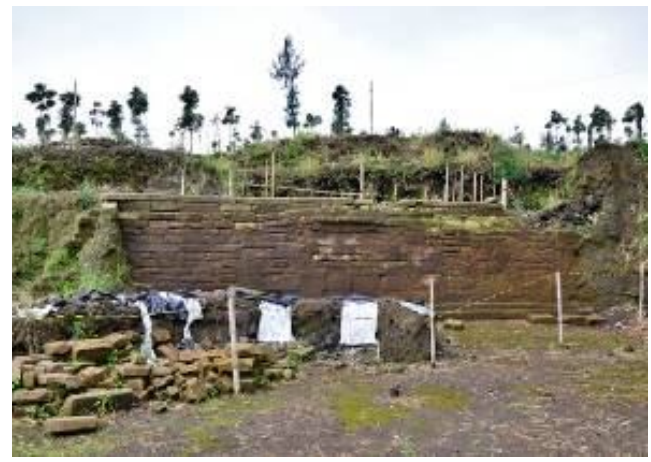

Gambar 14. Talud lempeng / balok batu di bagian atas situs, foto diambil tahun 2015
Hingga 2014 telah ditemukan dua struktur talud lempeng batu, yaitu tahun 2011 di dekat jalan batu dengan orientasi sejajar dengan jalan batu, dan pada ekskavasi 2012 di bagian atas situs. Selain kesamaan bahan dan kontruksinya, kesamaan lainnya adalah konteks dengan sisa bangunan kayu yang berada di atas talud.

Ukuran balok/lempeng batu penyusun struktur talud mempunyai panjang $42-82 \mathrm{~cm}$, lebar $26-28 \mathrm{~cm}$, dan tebal $12-15 \mathrm{~cm}$ sehingga bentuknya mirip lempengan atau balok batu. Batu penutup talud mempunyai panjang 96-110 cm, lebar $26-28 \mathrm{~cm}$, dan tebal $12-13 \mathrm{~cm}$. Batu fondasi talud mempunyai panjang $38-78 \mathrm{~cm}$, lebar $20-22 \mathrm{~cm}$, dan tebal $11-12 \mathrm{~cm}$.

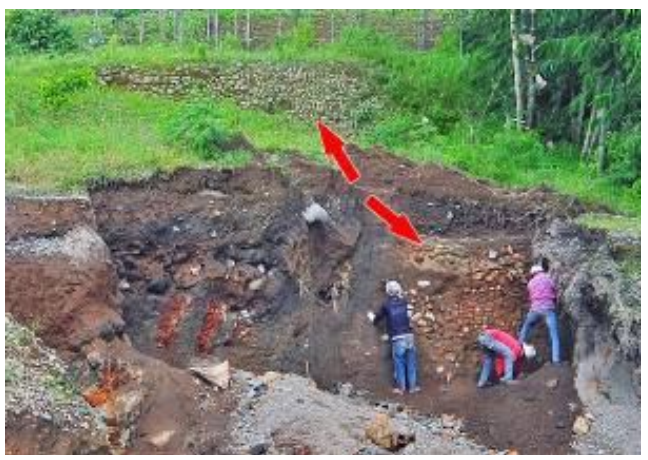

Gambar 15. Talud boulder hasil penelitian 2012 (atas) dan pada waktu ekskavasi 2013 (bawah)

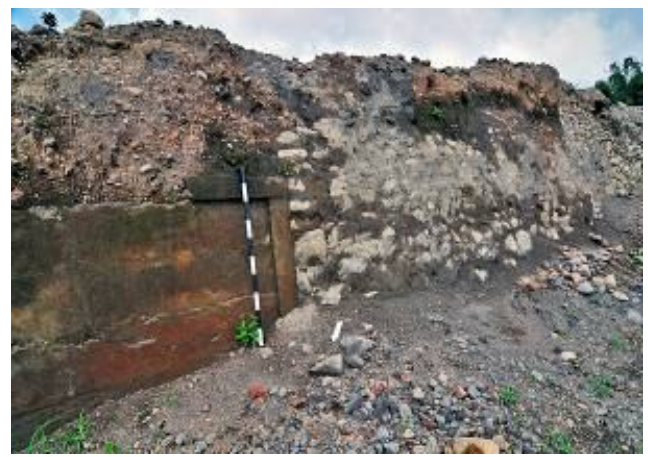

Gambar 16. Konstruksi boulder yang tersambung pada talud balok/lempeng batu. Foto diambil tahun 2014 
Hingga penelitian 2014 setidaknya telah ditemukan delapan struktur talud boulder di lokasi yang berbeda. Umumnya struktur talud boulder tidak berada di bagian tengah situs tetapi cenderung di bagian atas atau tepi dari area peribadatan.

Konstruksi berbahan boulder juga ditemukan sebagai kombinasi pada talud yang dibangun dari balok atau lempeng batu tufaan. Hal ini mengindikasikan adanya gejala renovasi yang dilakukan oleh masyarakat Liangan kuno pada masanya. Selain itu juga ditemukan konstruksi boulder yang tersambung dengan konstruksi talud berbahan balok batu tufaan. Satu struktur dengan bahan dan konstruksi yang berbeda tentunya memiliki arti tertentu, baik berkaitan dengan ketersediaan bahan maupun aspek lain yang belum diketahui

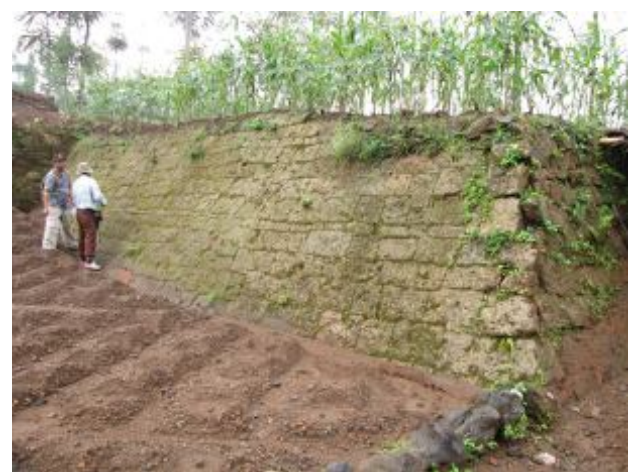

Gambar 17.Talud kubus batu yang terletak di barat sungai. Foto diambil tahun 2010

Disebut talud kubus batu karena pada awal ditemukan pada 2008, bahan yang tampak adalah batu-batu yang berbentuk menyerupai kubus. Struktur talud kubus batu dibangun dari balokbalok dan papan batu dan membentuk konstruksi yang cenderung memanjang dengan kemiringan sekitar $70^{\circ}$ dengan tinggi sekitar 2 meter. Diduga talud ini merupakan talud utama di situs
Liangan yang menahan lereng bukit paling atas dari area situs.

(3) Jalan, Selasar, dan Tangga

Keletakan data arkeologi berupa jalan, selasar, dan tangga di situs Liangan pada peta situasi situs adalah sebagai berikut.

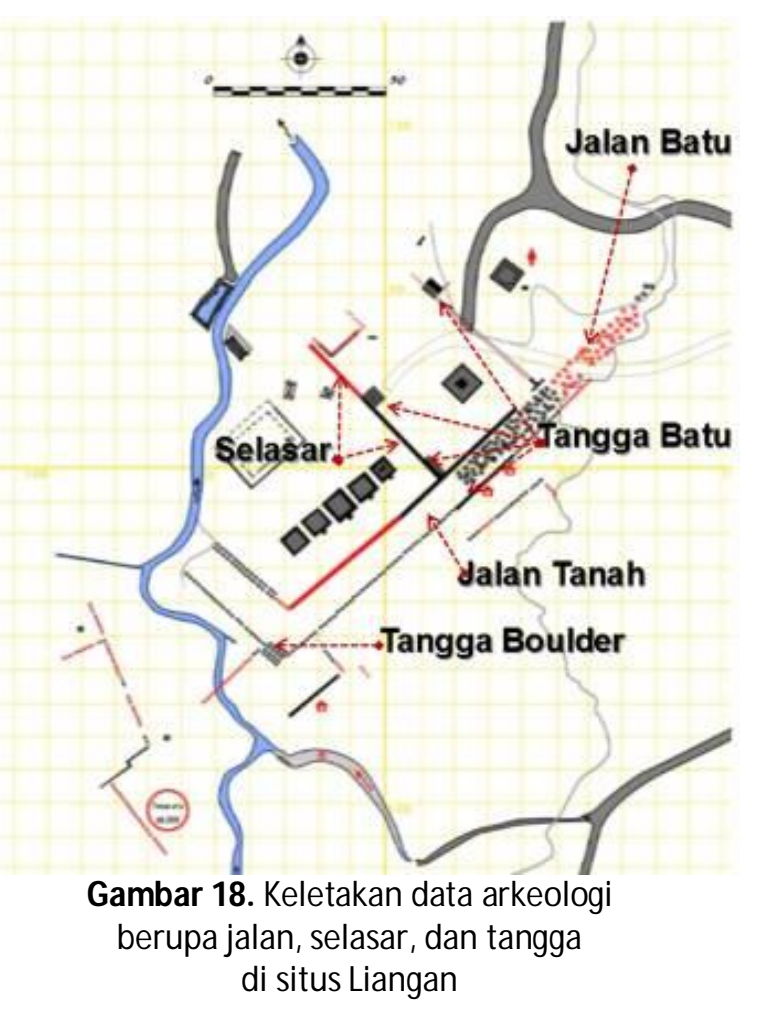

Berikut ini adalah uraian singkat mengenai fitur jalan, selasar, dan tangga yang ditemukan di situs Liangan hingga 2014.

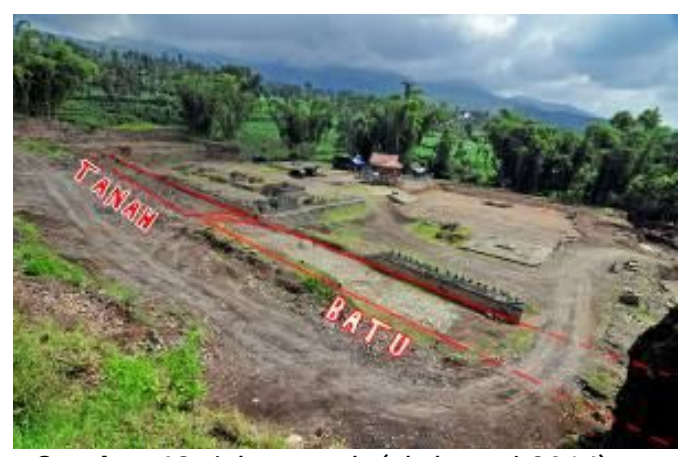

Gambar 19. Jalan tanah (ekskavasi 2014) dan jalan batu (ekskavasi 2012), foto diambil tahun 2014 
Jalan tanah dan jalan batu sebenarnya satu ruas, posisinya di sisi timur area peribadatan dan dipisahkan oleh pagar candi. Jalan tanah berada di bagian ujung atas sepanjang sekitar 30 meter, sedangkan jalan batu tersambung dengan jalan tanah terus ke bawah dengan panjang yang sudah tersingkap sekitar 100 meter. Diduga jalan ini merupakan akses utama yang menghubungkan ruang-ruang atau halaman-halaman yang ada di situs Liangan

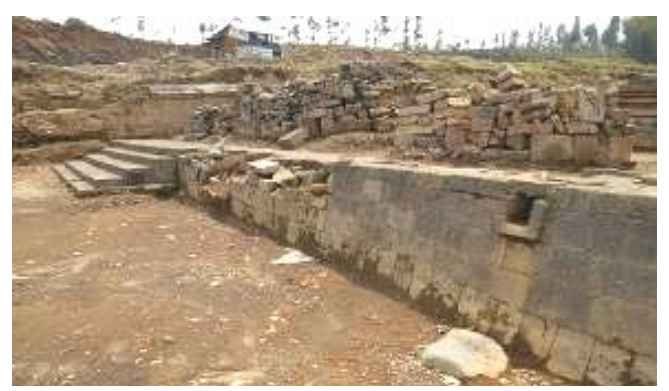

Gambar 20. Selasar hasil ekskavasi pada 2012. Foto diambil tahun 2014

Selasar

yang

menghubungkan halaman I dengan halaman II dilengkapi dengan dua tangga dalam jarak \pm 25 meter dan beberapa saluran air ini ditemukan dalam ekskavasi tahun 2012. Selasar di situs Liangan berupa tatanan balok batu andesit secara horisontal sepanjang \pm 30 meter dan lebar $\pm 1,5$ meter dengan orientasi tenggara - barat laut.

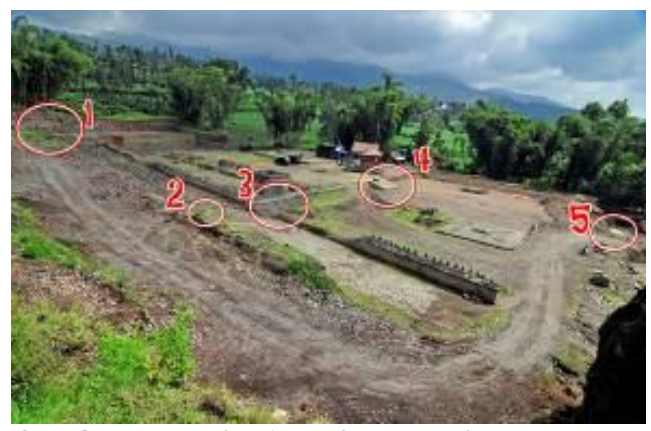

Gambar 21. Lokasi struktur-struktur tangga yang ditemukan di situs Liangan. Foto diambil tahun 2014
Hingga 2014, di situs Liangan telah ditemukan lima tangga, seperti tampak pada foto, yaitu: (1) tangga boulder, berada di ujung atas jalan tanah, (2) tangga talud berada di jalan batu dan dinding talud balok batu, (3) tangga selasar timur, (4) tangga selasar barat, dan (5) tangga yang menghubungkan halaman III dan halaman II (area ibadah).

\section{Lubang Bekas Tiang}

Jumlah fitur lubang yang ditemukan adalah 36 , sebagian besar (33 lubang) berbentuk bundar, dan tiga lainya berbentuk persegi. Bentuk lubang ini menjadi indikasi adanya penggunaan dua bahan tiang yang berbeda, yaitu bambu untuk lubang berbentuk bundar, dan tiang kayu untuk lubang berbentuk persegi. Menarik perhatian bahwa susunan lubang-lubang ini membentuk pola baris dua baris memanjang dengan orientasi tenggara-barat laut. Tiga lubang persegi yang kemungkinan bekas tiang kayu berada di bagian samping,hal ini menandakan sebagai tiang penguat struktur yang berbahan bambu dan kayu.

Secara pasti belum dapat diketahui bentuk utuh dari struktur bambu dan kayu yang membentuk jajaran memanjang sebanyak dua baris ini. Pembukaan kotak ekskavasi di sekitarnya, masih di dalam Lot atau Blok 1401, sangat penting artinya guna mendapatkan data lebih lengkap untuk mengetahui bentuk bangunan tersebut. Dugaan yang dapat dimunculkan adalah bentuk perancah yang ditopang oleh deretan pancang bambu dan bagian samping diperkuat dengan pancang kayu. Pada ketinggian tertentu dilengkapi dengan konstruksi bambu atau kayu yang rapat dalam posisi 
mendatar yang digunakan sebagai alas untuk menempatkan barangbarang tertentu (Tim Penelitian, 2014b: 81).

Pemikiran ini didukung dengan sejumlah temuan artefak wadah berbahan keramik dan tembikar yang posisi penemuannya berada di atas mainfield dan beberapa artefak tersebut masih menyisakan fragmen bambu yang menempel pada badan wadah. Selain itu sebuah fragmen arang kayu berbentuk persegi memanjang ditemukan di bagian bawah terasan, diduga karena patah kemudian terlempar pada waktu kejadian dinasti Tang dari abad ke-9 hingga abad ke-10 Masehi. Bentuk-bentuk barang keramik tersebut jika diurutkan berdasarkan kuantitas maka meliputi guci, tempayan, mangkuk, guci kecil, teko, guci bercerat, pasu, serta bentuk lain seperti botol, cawan, cepuk, vas, dan kendi. Kualitas keramik dapat diketahui berdasarkan daerah asalnya atau tempat pembuatnya. Barang keramik didominasi oleh barang dari Guangdong (Guangdongware), sementara barang dari Yue (Yueware) secara kuantitas di bawah barang Guangdong. Dengan demikian maka

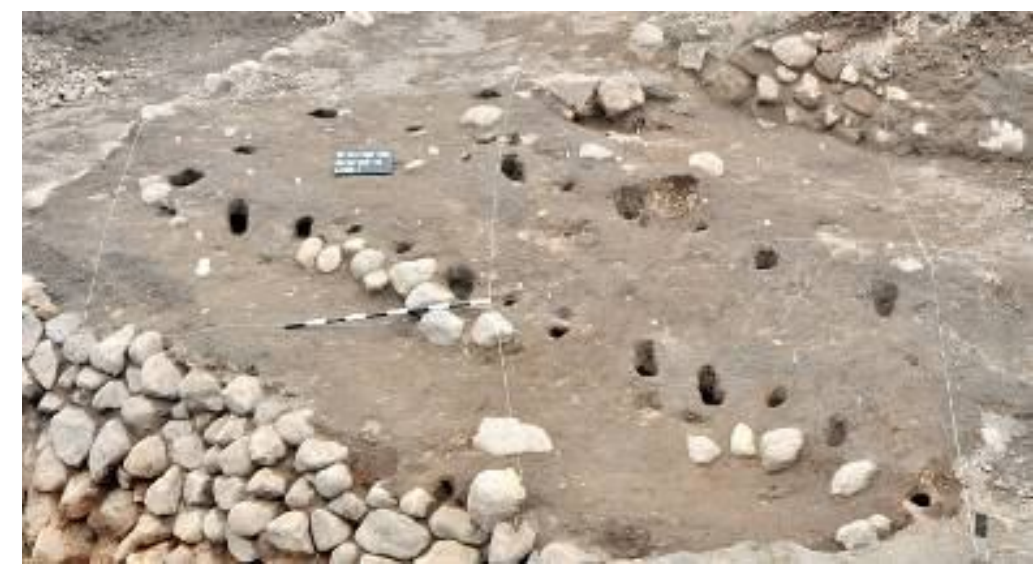

Gambar 22. Fitur lubang-lubang hasil ekskavasi 2014. Foto diambil tahun 2014

erupsi Sindoro pada abad X Masehi.

\section{Artefak}

Keragaman temuan artefak sebagai cermin dinamika kehidupan permukiman kuna Liangan merupakan bahan sangat penting untuk menggambarkan secara integral dengan keberadaan fitur seperti candi, batur, pagar, dan talud. Secara umum ragam temuan situs Liangan hingga 2014 meliputi artefak keramik, tembikar, batu, dan logam (Tim Penelitian, 2014a).

\section{Keramik}

Keramik yang ditemukan seluruhnya berasal dari Cina masa $\begin{array}{lll}\text { secara umum kualitas } & \text { keramik } \\ \text { Liangan tergolong } & \text { kualitas } \\ \text { menengah. } & & \end{array}$ Berikut adalah contoh artefak keramik dari situs Liangan yang sudah direkonstruksi dan dianalisis (Tim Penelitian, 2012b: 113-114). 


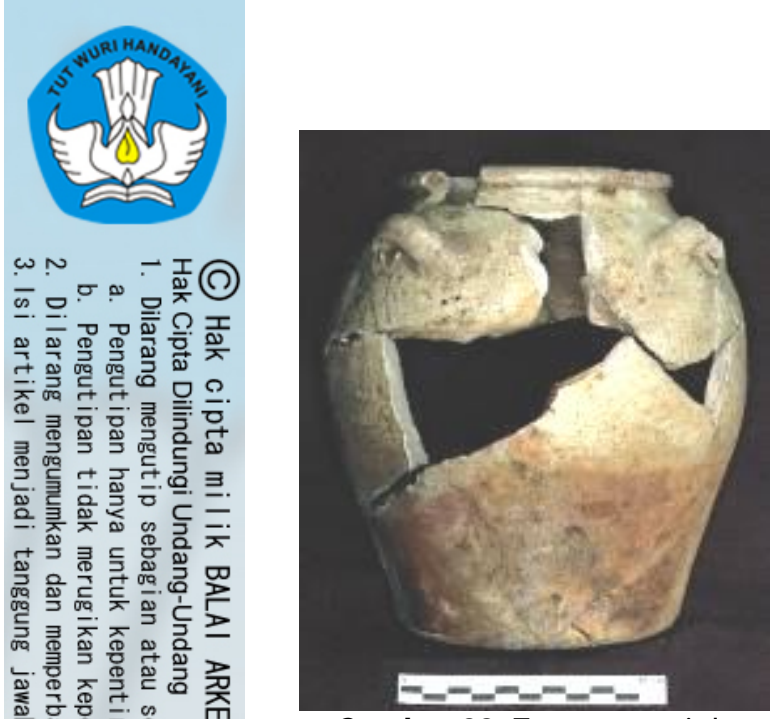

Gambar 23. Temuan guci dengan bibir rendah dan membulat

Bentuk : Guci

Asal : Cina, Guandong Ware Dinasti : Tang

Abad : 9-10 M

Tahun :-

Deskripsi:

Guci dengan bibir rendah dan membulat. Memiliki pegangan (4 buah) di bagian bahu horizontal. Diameter dasar lebar. Glasir kehijauan (celadon glaze).

Stoneware (bahan batuan). Guci semacam ini ditemukan pula di situs Candi Borobudur.

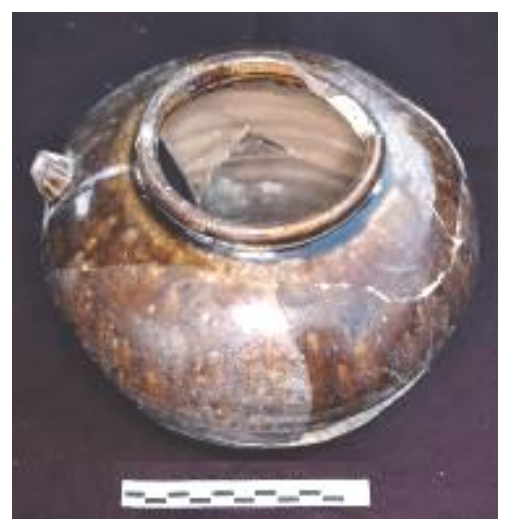

Gambar 24. Temuan guci bercerat

Bentuk: Teko/guci bercerat (ewer)

Asal : Cina, Guandong ware/ Yaozhao ware (?)

Dinasti : Tang

Abad : $9-10 \mathrm{M}$
Tahun :-

Deskripsi:

Guci dengan tepian/ bibir bulat dan rendah. Memiliki cucuk /cerat di bagian bahu (1 buah) berbentuk heksagonal (berukuran sekitar $2 / 3$ $\mathrm{cm}$ ?) yang menghadap ke atas. Bentuk cerat semacam itu umum dibuat pada barang-barang masa Dinasti Tang. Glasir Coklat gelap (dark-brown glaze). Stoneware (bahan batuan)

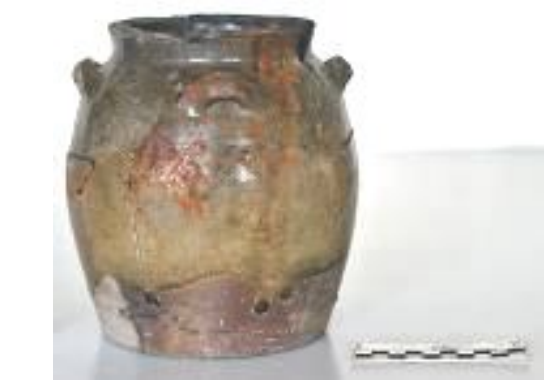

Gambar 25. Temuan guci dengan tepian rendah dan tegak lurus

Bentuk : Guci

Asal : Cina, Guandong ware

Dinasti : Tang

Abad : : $9-10 \mathrm{M}$

Tahun :-

Deskripsi : Tepian rendah dan berbentuk tegak lurus. Memiliki pegangan 4 buah horizontal pada bagian bahu. Diameter dasar lebar. Glasir hijau (green glaze).

Stoneware (bahan batuan)

\section{Tembikar}

Tembikar yang dianalisis memang baru sebagian, namun dari hasil analisis tersebut dapat dikenali beberapa hal penting tentang barang tembikar situs Liangan. Secara umum tembikar dibuat dari pasta kasar dengan campuran pasir dan sedikit di antaranya yang bercampur sekam. Teknik pembuatan umum roda putar dan beberapa di antaranya dibuat dengan teknik tekan atau gabungan antara teknik roda putar dan tekan. Hiasan 
tembikar umumnya goresan upam garis sejajar atau silang dan sedikit yang berhiaskan dengan teknik gores atau cungkil. Jenis barang tembikar yang dapat dikenali hingga 2014 berdasarkan kuantitas adalah: kendi, periuk, lampu, kowi, penyangga wadah, cawan, dan lainya berupa buyung, pasu, dan figurin burung (Tim Penelitian, 2012a dan 2014a).
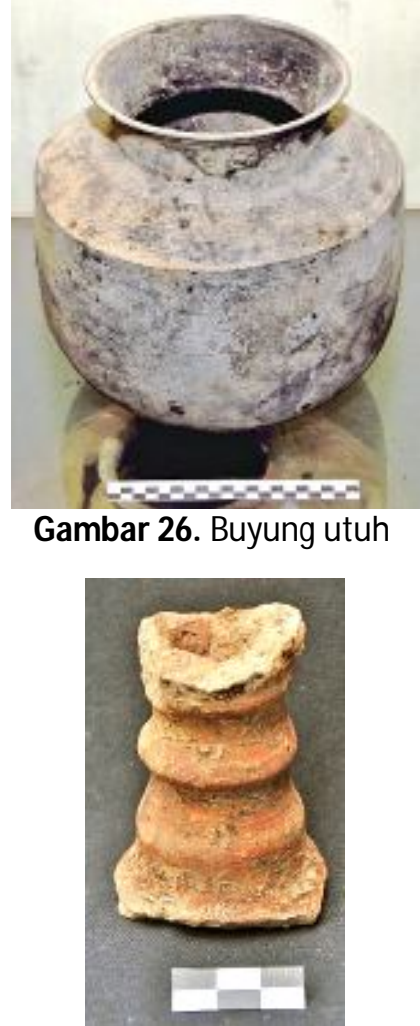

Gambar 27. Fragmen leher kendi

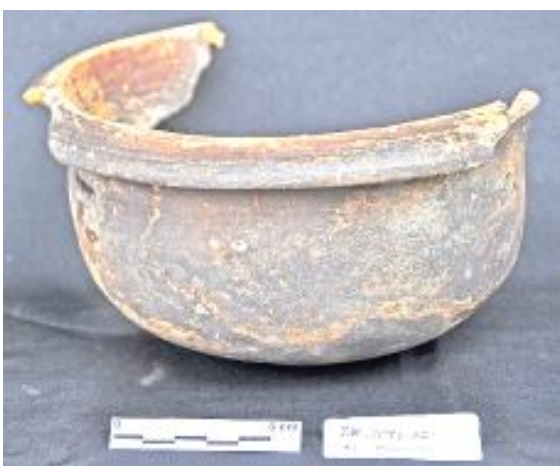

Gambar 28. Periuk utuhan

\section{Artefak Batu}

Untuk artefak batu, hasil analisis menunjukkan tingkat keragaman yang rendah, yaitu meliputi pipisan, gandik, dan plat batu. Menarik untuk dicatat bahwa gandik dan pipisan memilki ukuran yang tidak seragam meskipun secara umum bentuknya satu tipe. Variasi bentuk pipisan terutama ada pada bagian ujung dan bagian kaki. Beberapa gandik dan pipisan menunjukkan gejala jejak pakai yang cukup kentara, sehingga dipastikan barang-barang ini benarbenar pernah digunakan pada masa lalu. Selain itu, data arkeologi berbahan batu yang ditemukan di situs Liangan juga meliputi yoni, arca gajah, arca Ganesa (2 buah), arca wanita, arca manusia, dan satu butir manik-manik(Tim Penelitian, 2014a dan 2014b).

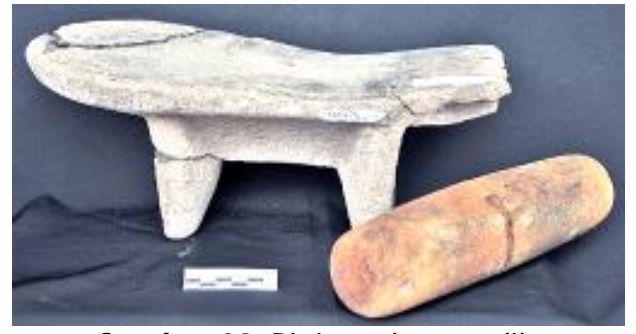

Gambar 29. Pipisan dan gandik

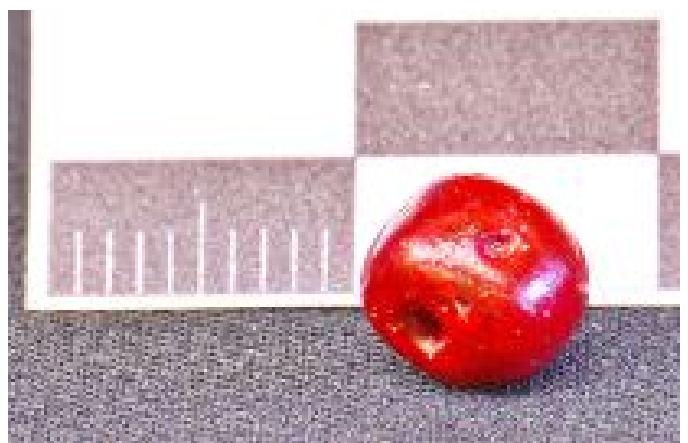

Gambar 30. Manik-manik berbahan batu 
Artefak Logam

Hasil analisis artefak logam menunjukkan tingkat varian yang tinggi dan dapat dikelompokkan berdasarkan kategori tertentu. Berdasarkan kategorinya, maka

Tabel 1. Analisis temuan artefak logam

\begin{tabular}{|c|c|c|c|}
\hline KATEGORI & NAMA BENDA & JUM BEN & JUM KAT \\
\hline alat bangunan & angkor & 7 & 7 \\
\hline \multirow{3}{*}{ alat pertanian } & cangkul (?) & 1 & \multirow{3}{*}{7} \\
\hline & parang & 5 & \\
\hline & fr. sabit & 1 & \\
\hline \multirow{6}{*}{$\begin{array}{l}\text { alat rumah } \\
\text { tangga }\end{array}$} & buyung, bagian tepian sampai badan & 1 & \multirow{6}{*}{20} \\
\hline & mangkuk & 4 & \\
\hline & panci & 2 & \\
\hline & pisau & 2 & \\
\hline & talam & 10 & \\
\hline & tangkai wadah & 1 & \\
\hline \multirow{5}{*}{$\begin{array}{l}\text { alat / tukang } \\
\text { alat pande }\end{array}$} & cungkil & 3 & \multirow{5}{*}{28} \\
\hline & kapak & 5 & \\
\hline & fr. palu & 6 & \\
\hline & tatah & 10 & \\
\hline & tang & 3 & \\
\hline alat upacara & giring-giring & 1 & 1 \\
\hline \multirow{2}{*}{ penerangan } & lampu gantung & 6 & \multirow{2}{*}{7} \\
\hline & tempat minyak & 1 & \\
\hline perhiasan & cermin / darphana & 1 & 1 \\
\hline \multirow{3}{*}{ senjata } & pedang & 3 & \multirow{3}{*}{10} \\
\hline & keris & 3 & \\
\hline & tombak & 4 & \\
\hline UI & UI & 1 & 1 \\
\hline
\end{tabular}

artefak logam situs Liangan setidaknya meliputi benda sebagaimana terlihat pada tabel berikut ini(Tim Penelitian, 2014a dan 2014b): : 


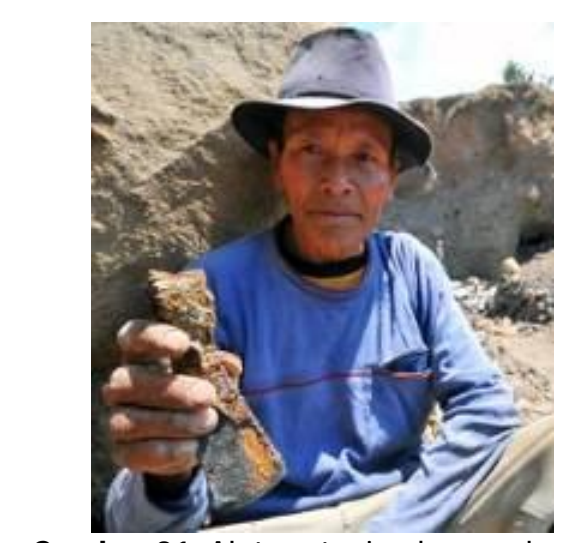

Gambar 31. Alat pertanian berupa kapak besi, ditemukan oleh penambang pada 2012. Foto tahun 2012

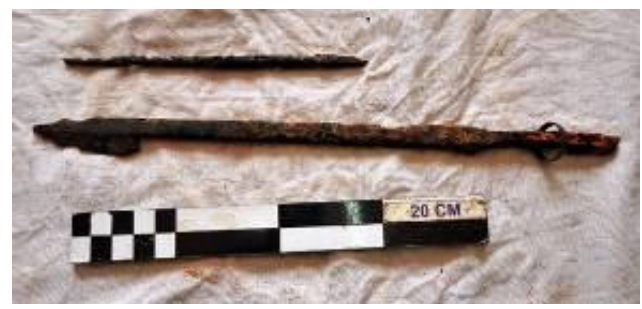

Gambar 32. Artefak logam kategori senjata berupa mata tombak (bawah) dan lancipan (atas) berbahan besi yang ditemukan penambang pada 2013. Foto diambil pada tahun 2013

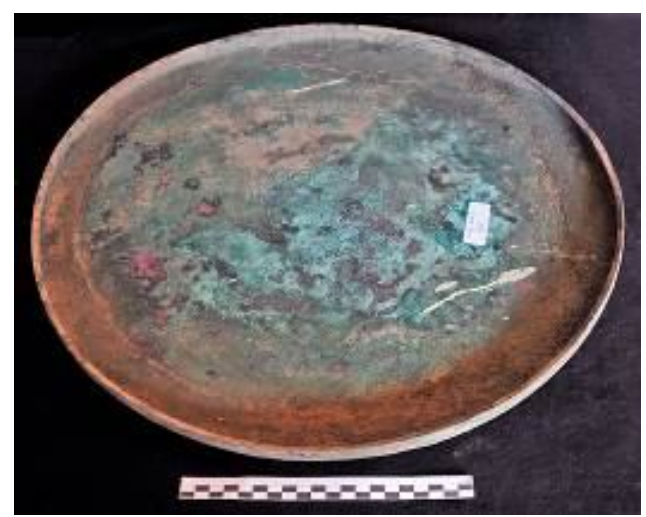

Gambar 33. Salah satu talam perunggu temuan penambang tahun 2013, bagian tengahnya berhias sangkha bersayap. Foto tahun 2014

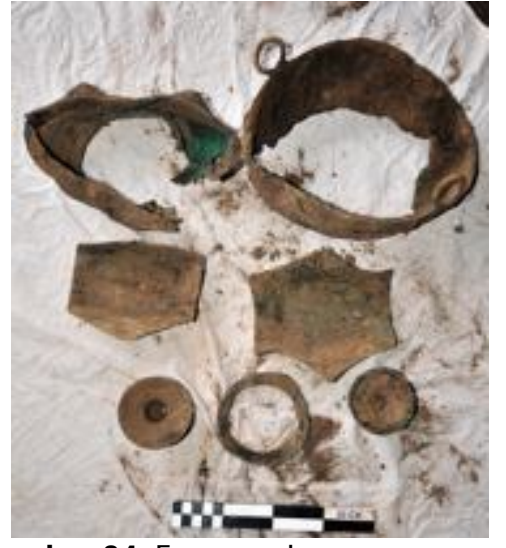

Gambar 34. Fragmen lampu perunggu

(lampu gantung ?), penemuan oleh penambang pada 2013. Foto tahun 2013

\section{DataOrganik}

Secara umum data organik yang ditemukan di situs Liangan hingga 2014 meliputi beberapa jenis yang dapat dikelompokkan dalam kategori artefak, bahan pangan, komponen bangunan, tanaman, tulang fauna, serta fragmen rangka manusia. Sebagian besar data organik tersebut ditemukan oleh penambang di ruang $F$ dan sebagian lainnya merupakan hasil ekskavasi. Berikut ini adalah ringkasan mengenai data organik tersebut (Tim Penelitian, 2014a).

(1) Pada kategori artefak, data organik meliputilembaran kain, kantong kain, lembaran yang diduga terbuat dari kulit kayu yang seluruhnya ditemukan dalam kondisi rapuh karena terbakar

(2) Data organik kategori bahan pangan meliputigabah, jagung, pala, kelapa, kluwak (?), dan bijibijian juga ditemukan dalam bentuk arang

(3) Kategori komponen bangunan meliputifragmen kayu dalam berbagai bentuk dan ukuran yang jelas mengalami pengerjaan, bambu dalam bentuk utuh maupun anyaman, dan ijuk 
(4) Benda-benda organik yang termasuk kategori tanaman meliputi kayu pohon dan bambu yang tidak mengindikasikan pengerjaan sehingga diduga merupakan sisa pohon

(5) Fragmen tulang faunayang umumnya jenis bovidae merupakan sisa konsumsi sebagaimana tampak pada indikasi bekas potongan sehingga secara hipotetik bukan korban letusan meskipun sebagian dalam kondisi terbakar

(6) Fragmen rangka manusia yang ditemukan berupa tengkorak bagian belakang, tulang satu potong panjang, dan geligi. Hasil analisis menunjukkan bahwa sisa rangka itu berjenis kelamin perempuan berumur sekitar 22 tahun. Berdasarkan buli-buli keramik Cina dari masa Dinasti Tang abad IX Masehi, maka diperkirakan wanita tersebut sejaman dengan situs Liangan

\section{Data Geologi}

Hasil kajian geologis di situs Liangan dan sekitarnya menunjukkan bahwa materi vulkanik Gunung Sindoro adalah faktor utama yang mengubur permukimanLiangankuno dengan beberapa spesifikasi sebagai berikut (Tim Penelitian, 2014a).

- Endapan jatuhan piroklastik berselang-seling dengan lava dan aliran piroklastik, hal ini mencerminkan bahwa setiap kali letusan, gunungapi Sindoro selalu menghasilkan endapan jatuhan piroklastik

- Bagian bawah situs Liangan berupa endapan jatuhan piroklastik yang tak teruraikan dengan penyebaran yang sangat luas, hampir $75 \%$ menutupi tubuh gunungapi Sindoro
- Potensi bencana di situs Liangan meliputi gempa vulkanik, aliran piroklastik, awan panas, lahar dingin, lahar panas, dan aliran lava.

- Setidaknya ada dua bencana yang pernah melanda Situs Liangan dengan tingkat rendah-sedang hingga tingkat tinggi atau berat.

- Erupsi Gunung Sindoro menyebabkan Situs Liangan terkuburoleh aliran piroklastik bercampur dengan awan panas dan aliran lava yang terus berlangsung, disusul dengan aliran lahar dingin dan membentuk Kali Langit yang akhirnya memisahkan bangunan-bangunan di situs Liangan yang awalnya satu kesatuan 


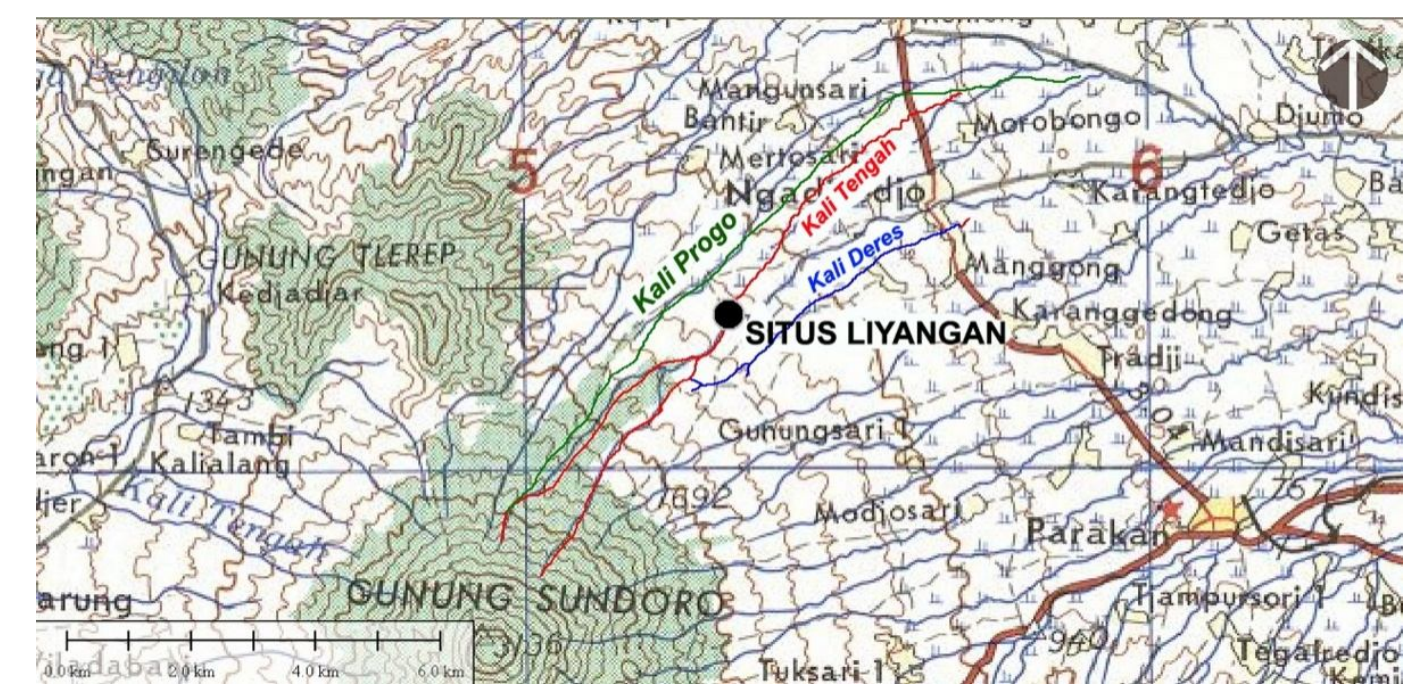

Gambar 35. Keletakan Situs Liangan terhadap Gunung Sindoro, Kali Progo, Kali Deres, dan Kali Langit pada peta topografi (diolah oleh Fadhlan S. Intan)

\section{KRONOLOGI}

Kronologi situs Liangan didasarkan pada gaya bangunan candi 1, khususnya profil bagian kaki, keramik, dan analisis carbon 14. Profil bagian kaki candi 1 yang meliputi bentuk sisi genta, setengah lingkaran, dan pelipit persegi adalah gaya bangunan candi masa Mataram Kuno di Jawa Tengah sekitar abad VIII - X Masehi. Temuan keramik yang seluruhnya berasal dari Cina masa Dinasti Tang mengacu pada kronologi sekitar abad IX atau awal abad X Masehi (Riyanto, 2013: 775). Hasildating melalui analisis carbon pada sampel arang bambu dan kayu yang dicuplik dari beberapa lokasi di situs Liangan menghasilkan angka kalender 587 Masehi, 742 Masehi, 846 Masehi, 913 Masehi, dan 971 Masehi. Hal ini menunjukkan bahwa permukiman Liangan Kuno telah hadir setidaknya sejak abad $\mathrm{VI}$ hingga abad $\mathrm{X}$ Masehi.

Rentang kronologis sebagaimana dijelaskan di atas memberi arti bahwa situs Liangan merupakan situs masa klasik, khususnya jika mengacu bahwa masa klasik di Indonesia merupakan rentang waktu ketika anasir kebudayaan dari India yang diilhami oleh ide-ide dalam agama Hindu dan Buddha sangat menonjol dan cukup kuat dalam peradaban. Secara formal masa klasik sebagai sebuah kajian dalam arkeologi berada pada rentang waktu sekitar abad V - XVI Masehi (Satari, 2002: 61). Secara lebih spesifik, permukiman Liangan kuno dapat dimasukkan pada kerangka kronologis masa Mataram Kuna karena masa ini berlangung sekurang-kurangnya dari abad VIII hingga abad $X$ di Jawa dan sering dikaitkan dengan Dinasti Syailendra dengan Dapunta Selendra sebagai cikal bakalnya (Sedyawati dkk., 2012: 172-177). Kronologi situs Liangan yang berada di antara abad VI hingga abad $X$ Masehi jelas dapat dimasukkan ke dalam kerangka sejarah Mataram Kuno tersebut, bahkan "menyisakan" dua abad lebih awal. Berdasarkan hal itu maka secara hipotetik, situs Liangan telah menjadi lokasi hunian sebelum kerajaan Mataram Kuno "berdiri". 


\section{ASPEK KERUANGAN}

Gambaran umum aspek keruanganhingga penelitian 2014a adalah sebagai berikut.

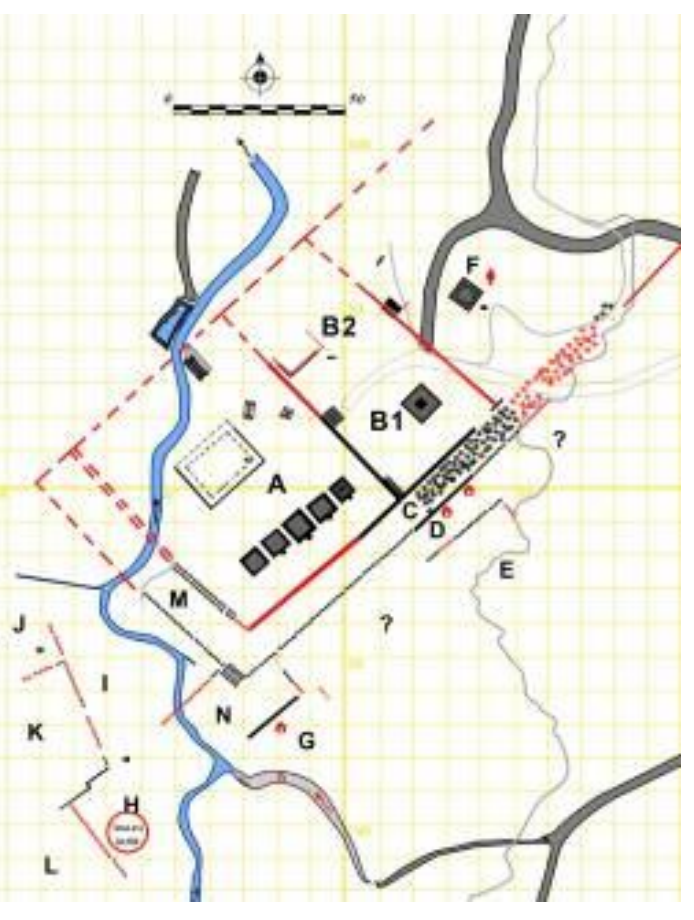

Gambar 36. GaAspek keruangan situs Liangan hasil ekskavasi hingga 2014a

Penambahan data fitur, koreksi identifikasi batur 4 menjadi candi 2, serta komponen yang ditemukan pada 2014 menjadi kelengkapan penting untuk menyusun hubungan keruangan di situs Liangan, khususnya area peribadatan yang terdiri atas ruang $F$, ruang $B$, dan ruang $A$. Berdasarkan analisis keruangan, maka ketiganya dapat digambarkan sebagai kesatuan yang terintegrasi dalam satu area peribadatan yang membentuk tiga halaman. Ketiga halaman itu jika dimulai dari bawah, yaitu ruang $\mathrm{F}$ menjadi halaman III, ruang $B$ menjadi halaman II, dan ruang $A$ menjadi halaman utama atau halaman I. Penemuan tangga yang langsung menghubungkan ruang $F$ dengan ruang di atasnya sangat penting artinya dalam konsep keruangan ini.

Berdasarkan komponen keruangan dan relasional antarruang maka diperoleh gambaran tentang dinamika prosesi ritual di area peribadatan situs Liangan. Gambaran hipotetik tersebut adalah sebagai berikut. Jika mulai dari candi 2 di halaman III (area F) prosesi dilanjutkan menuju halaman II (ruang B) melalui tangga. Prosesi kemudian dilanjutkan dari tangga ke batur 4 untuk kemudian menuju batur 3 melalui tangga selasar. Selanjunya, dari batur 3 prosesi utama dimulai dengan didahului prosesi di batur $2 \mathrm{~d}, 2 \mathrm{c}, 2 \mathrm{~b}, 2 \mathrm{a}$, dan akhirnya sampai pada prosesi puncak di candi 1 . Selanjutnya, dari candi 1 , seusai prosesi, maka keluar lewat tangga selasar untuk kemudian "singgah" di batur nomor 2. Terakhir adalah keluar dari area peribadatan melalui sela antara pagar candi dan pagar balok batu untuk turun melalui jalan batu atau naik juga melalui jalan batu (Tim Penelitian, 2014a). 


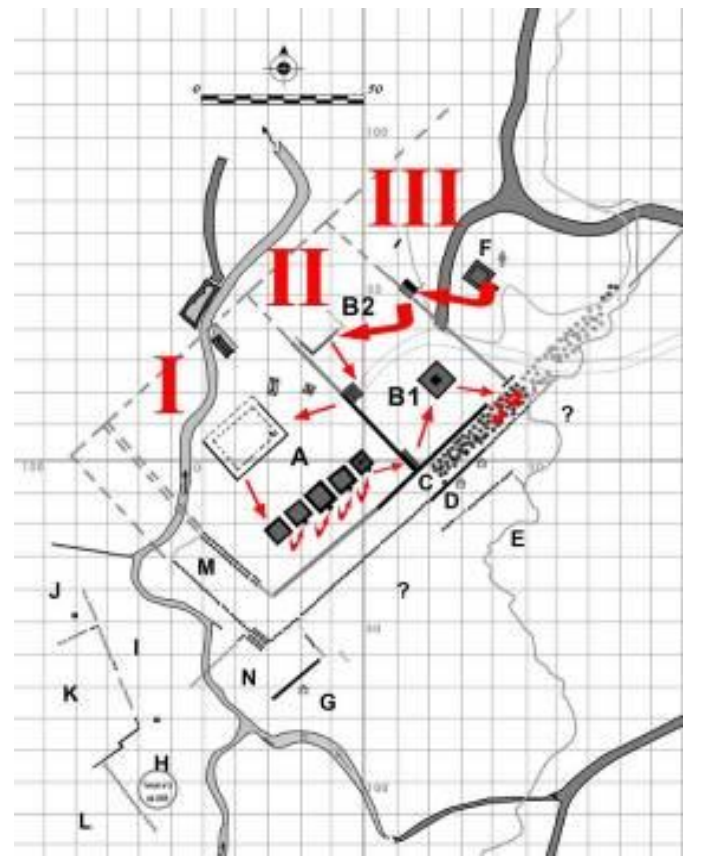

Gambar 37: Gambaran hipotetik urutan prosesi peribadatan berdasarkan komponen dan formasi keruangan situs Liangan

Hasil ekskavasi pada 2014b memunculkan pandangan baru mengenai fungsi ruang III dan IV yang sebelumnya secara hipotetik sebagai ruang hunian, namun setelah ditemukan candi 2 dan bangunan di halaman IV pandangan tentang fungsi halaman sedikit berubah, yaitu sebagai hunian yang menyatu dengan tempat awal prosesi ibadah. Bukan hanya itu, temuan tersebut juga membawa ke pemikiran bahwa ruang III dan IV sepenuhnya merupakan bagian dari area ibadah, adapun dominasi ragam temuan di tempat itu,seperti perkakas rumah tangga dan bahan makanan, kemungkinan merupakan bagian dari kelengkapan prosesi. Pandangan terakhir tidak sepenuhnya selaras dengan ragam temuan yang mengindikasikan dinamika hunian seperti peralatan memasak, perlengkapan makanminum, senjata, alat-alat pertanian, dan bangunan-bangunan kayu.

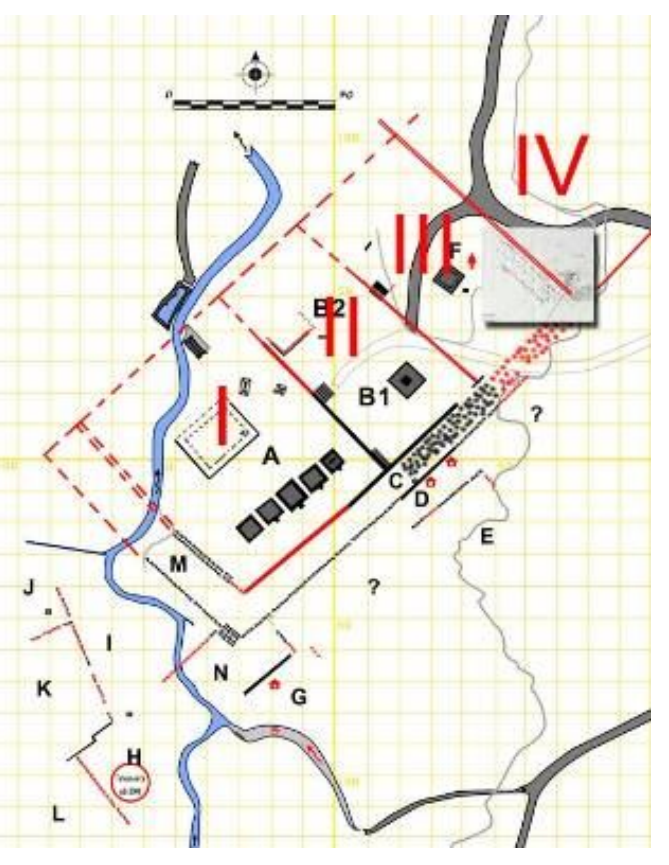

Gambar 38: Gambaran keruangan situs Liangan hingga ekskavasi 2014b

\section{PENUTUP}

Sebagai penutup tulisan ringkas mengenai ragam data, kronologi, dan aspek keruangan situs Liangan ini, berikut diajukan beberapa gagasan yang penting untuk dilakukan di masa datang, khususnya berkaitan dengan penelitian dan pengelolaan situs Liangan. Pertama, tentang pandangan dasar bahwa Liangan bukanlah situs candi tetapi situs permukiman yang kompleks dan harus menjadi landasan bagi seluruh stakeholders dalam menangani situs Liangan. Keragaman data yang hadir jelas tidak dapat dibantah merupakan pijakan pandangan dasar itu, sehingga seluruh data memiliki kedudukan dan peran yang sama secara integral, baik data berupa struktur dan bangunan batu, fitur lain, artefak, organik, serta data lingkungan geologis. Kronologi yang menunjuk pada abad VI - X Masehi adalah unik, bukan hanya karena durasi hunian yang lama, yaitu 
sekitar empat abad, tetapi juga adanya indikasi hunian masa praMataram Kuna, bahkan tidak menutup kemungkinan masa praHindu. Keragaman data juga menjadi salah satu cermin dinamika permukiman, setidaknya meliputi dinamika hunian, dinamika peribadatan, dinamika pertanian, dan sangat mungkin adanya dinamika perbengkelan sebagaimana tampak dari kompleksitas dan rumitnya komponen maupun formasi keruangan situs Liangan.

Kedua, berkaitan dengan arah dan sasaran penelitian yang harus disusun secara sistematis, bahkan jika memungkinkan juga terukur. Hasil penelitian hingga 2014 tidak bisa tidak, merupakan acuan bagi kerangka penelitian tahap-tahap berikutnya, acuan bagi kerangka pelaksanaan pelestarian, dan acuan bagi kerangka pengembangan. Dalam kerangka penelitian, setidaknya terdapat tujuh aspek yang perlu dijadikan sasaran penelitian, yaitu:

(1) Keruangan dan luasan situs, meskipun telah diperoleh gambaran tentang keruangan situs namun berbagai permasalahan masih perlu dipecahkan, baik yang berkaitan dengan komponen keruangan, adanya ruang-ruang yang masih tertimbun materi vulkanik, tentang konsep tata ruang, serta gambaran keluasan situs yang lebih akurat

(2) Kronologi dan kerangka historis yang mencakup perkembangan dan fase-fase permukiman serta kedudukan situs Liangan di dalam dinamika peradaban Mataram Kuna, termasuk hubungan dengan mancanegara
(3) Konsep religi yang mencakup "kepercayaan asli", awal pengaruh Hindu, hingga masa Mataram Kuna

(4) Dinamika permukiman yang berkenaan dengan pranata sosial, ekonomi, teknologi, keseharian, dan perbengkelan; salah satunya adalah dengan mendalami karagaman temuan artefaktual melalui analisis yang lebih spesifik

(5) Arkeobotani yang meliputi aspek pertanian dan jenis-jenis vegetasi maupun tanaman budidaya pertanian

(6) Arsitektur dan teknologi sipil yang secara khusus diarahkan untuk mendapatkan pengetahuan tentang struktur dan bangunan di situs Liangan berkenaan dengan prinsipprinsip arsitektur dan teknologi bangunan

(7) Geologi situs Liangan yang merinci stratigrafi berkaitan dengan kronologi letusan Gunung Sindoro, jenis dan kekuatan letusan, serta pengaruhnya pada situs Liangan dan situs-situs yang semasa, maupun pengaruhnya pada lingkungan yang berada di sekitarnya.

Ketiga, berkaitan dengan arah dan sasaran pengembangan, dalam hal ini setidaknya ada dua gagasan, yaitu:

(1) Konsep pengelolaan dan pengembangan yang meliputi pengelolaan data di lapangan baik data arkeologi seperti fitur, bangunan, dan data organik, maupun data lingkungan seperti stratigrafi geologis sebagai dokumen erupsi dan kebencanaan, serta artefakekofak dalam ruang khusus yang 
didukung dengan $d B a s e$ integral. Selain itu, sasaran tersebut juga mencakup pengembangan yang meliputi pengembangan sistem informasi situs Liangan dan konsep pemanfaatan yang berkesinambungan dan partisipatoris dengan visi "Taman Konservasi Liangan". Konsep ini antara lain meliputi penyusunan peta stakeholders, peta kecenderungan, peta potensi pendukung, peta problematika, serta analisis SWOT. Dengan demikian maka nantinya sektorsektor terkait dan seluruh sumberdaya terkait, bukan hanya situs, dapat dikembangkan bersama-sama secara integral

(2) Transformasi pekerja tambang menjadi pekerja situs adalah usaha melalui kajian khusus manajemen sumberdaya arkeologi dan arkeologi publik yang bertujuan untuk mengalihkan kegiatan warga Liangan yang tadinya bekerja sebagai penambang menjadi warga yang bekerja untuk kepentingan situs Liangan 


\section{DAFTAR PUSTAKA}

Azwar, Saifuddin. 1998. Metode Penelitian. Yogyakarta: Pustaka Pelajar.

Boechari, 1977. "Candi dan Lingkungannya" dalam Majalah IImu-ilmu Sastra Indonesia. Jili VII, No. 2, Juli 1977, pp. $89-114$

Bosch, F.D.K. 1974. Masalah Penyebaran Kebudayaan Hindu di Kepulauan Indonesia, terj. LIPI-KITLV. Jakarta: Bhratara.

Clark, David L. 1977. "Spatial Information in Archaeology". Spatial Archaeology. London: Academic Press. Pp. 1-32

Danim, Sudarwan. 2002. Menjadi Peneliti Kualitatif. Bandung: Pustaka Setia.

Haryono, Timbul. Metodologi dan Aplikasinya dalam Penelitian Arkeologi, dalamArtefak No. 13 Agustus 1993, pp. 9-14.

Mundardjito. 1990. "Metode Penelitian Permukiman Arkeologis", Monumen, Karya Persembahan Untuk Prof. Dr. R. Soekmono. Depok: Lembaran Sastra Universitas Indonesia. Pp. 19-31.

Mundardjito. 2002. "Arkeologi Keruangan: Konsep dan Cara Kerjanya", dalam Kumpulan Makalah Pertemuan IImiah Arkeologi VII. Jakarta: Ikatan Ahli Arkeologi Indonesia. Pp. $70-75$.

Rangkuti, Nurhadi dan Baskoro DT. Laporan Peninjauan Situs Liangan, Temanggung, Jawa Tengah. 2000. Tidak terbit

Riyanto, Sugeng. 2011. "Integrasi Data, Gambaran Rekonstruktif, dan Kronologi Situs Liangan", dalam Berita Penelitian Arkeologi. Nomor: 25, Pp 45-61

Riyanto, Sugeng. 2013. "Letusan Gunung Sindoro Mengubur Situs Mataram Kuno Liyangan", dalam Arkeologi, Sejarah, dan Budaya. Prosiding Seminar Antarbangsa ke-2 Arkeologi, Sejarah, dan Budaya di Alam Melayu 26-27 November 2013 di Universiti Kebangsaan Malaysia. Bangi: Istitut Alam dan Tamadun Melayu, Universiti Kebangsaan Malaysia. Pp. $767-781$

Said, Chaksana A.H. 2006. "Permukiman dalam Perspektif Arkeologi". Permukiman di Indonesia Perspektif Arkeologi. Jakarta: Pusat Penelitian dan Pengembangan Arkeologi Nasional. Pp. 1-15

Satari, Sri Soejatmi. 2002. "Penyerapan dan Pemanfaatan Aspek Budaya HinduBuddha dalam Masyarakat Masa Kini", dalam Kumpulan Makalah Pertemuan IImiah Arkeologi VII. Jakarta: Ikatan Ahli Arkeologi Indonesia. HIm. $61-63$. 
Sedyawati, Edi et.al. 2012. "Dinasti, Agama, dan Moumen". Indonesia Dalam Arus Sejarah, Kerajaan Hindu-Buddha. Jakarta: PT Ichtiar Baru Van Hoeve. Pp. 171-203

Sumanto. 1995. Metodologi Penelitian Sosial dan Pendidikan. Yogyakarta: Penerbit Andi Offset.

Tim Penelitian Balai Arkeologi Yogyakarta. 2011. Laporan Penelitian Situs Liyangan, Temanggung, Jawa Tengah. Tidak terbit.

Tim Penelitian Balai Arkeologi Yogyakarta. 2012a. Laporan Penelitian Situs Liyangan, Temanggung, Jawa Tengah. Tidak terbit.

Tim Penelitian Balai Arkeologi Yogyakarta. 2012b. Laporan Penelitian Situs Liyangan, Temanggung, Jawa Tengah. Tidak terbit.

Tim Penelitian Balai Arkeologi Yogyakarta. 2014a. Laporan Penelitian Situs Liyangan, Temanggung, Jawa Tengah. Tidak terbit.

Tim Penelitian Balai Arkeologi Yogyakarta. 2014b. Laporan Peninjauan Situs Liyangan, Temanggung, Jawa Tengah. Tidak terbit. 
